\title{
STRATEGI PENDIDIKAN NILAI DALAM MEMBENTUK KARAKTER \\ PESERTA DIDIK DI MI MATHOLIBUL HUDA JENGGOLO JENU TUBAN
}

\author{
Oleh: Siti Nurjanah
}

\begin{abstract}
The reality of children today tends to be far from positive values, family education is the first and foremost education in instilling values to children, but school is a vital place that has an important role to introduce and instill values to children so as to shape the character in the child. So this study aims to determine the value of education strategies in shaping the character of learners in MI Matholibul Huda jenggolo Jenu Tuban.

This research is included in descriptive qualitative research which is intended to understand what phenomena experienced by research subjects. The results showed that the strategy of values education in shaping the character of children is as follows first, exemplary strategy; second, advice (traditional); third, Knowing the good strategy; fourth, habituation strategy; fifth, the strategy of feeling and loving the good (feel good). While the impact of value education on the character of the child that includes: honest, discipline, responsibility, hard work, independent, creative, confident, religious, compassionate, appreciate Achievement, friendly / communicative, healthy lifestyle, courage, social care, and polite
\end{abstract}

Key Words: Pendidikan Nilai, Karakter 


\section{PENDAHULUAN}

Pendidikan karakter merupakan sebuah istilah yang semakin hari semakin mendapatkan perhatian masyarakat Indonesia saat ini. Pendidikan Karakter di Indonesia dirasakan amat perlu pengembangannya bila mengingat makin meningkatnya tawuran antar pelajar, perkembangan seks bebas pada kalangan remaja, narkoba, pembunuhan, perampokan serta bentuk-bentuk kenakalan yang lainnya.

Berbagai usaha dilakukan oleh pendidik untuk menanamkan nilai-nilai karakter dalam diri peserta didik, diantaranya adalah mendirikan kantin kejujuran namun yang paling memprihatinkan, keinginan untuk membangun sifat jujur anak-anak melalui kantin kejujuran di sejumlah sekolah, banyak yang gagal, karena belum bangkitnya sikap jujur pada anak-anak. Oleh karena itu betapa pentingnya penanaman pendidikan nilai agar terbentuknya karakter dalam diri anak.

Pendidikan karakter dengan melakukan usaha sungguh-sungguh, sistematik dan berkelanjutan untuk membangkitkan dan menguatkan kesadaran serta keyakinan bahwa tidak ada masa depan yang lebih baik yang bisa diwujudkan tanpa kejujuran, tanpa meningkatkan kedisiplinan diri, tanpa semangat belajar, tanpa mengembangkan rasa tanggung jawab, serta tanpa rasa percaya diri dan optimisme. Dalam hal ini sekolah/madrasah merupakan wadah yang punya peran sangat penting untuk mengenalkan dan menanamkan nilai kepada anak sehingga dapat membentuk karakter dalam diri anak.

Dengan demikian melalui pendidikan di Madrasah, anak harus diajarkan dengan berbagai nilai-nilai yang dapat mengembangkan diri baik dari segi ilmu pengetahuan, kreativitas, moral, karakter dan akhlak. MI Matholibul Huda memiliki cara dan strategi tersendiri dalam menanamkan nilai-nilai karakter bagi peserta didiknya agar anak dapat menerapkannya dalam kehidupan nyata baik di Madrasah maupun lingkungannya. Dari permasalahan di atas, hal inilah yang menarik bagi peneliti untuk meneliti lebih juah mengenai strategi pendidikan nilai yang ada di MI Matholibul Huda. 


\section{KAJIAN TEORI}

\section{Pendidikan nilai}

Nilai adalah suatu perekat keyakinan atau perasaan yang diyakini sebagai suatu identitas. Menurut St Vembriarto nilai adalah suatu yang menjadi unsur pembentuk kepribadian manusia, nilai bersumber dan diukur menurut pengalaman yang mencakup nilai spiritual, intelektual, emosional, sosial dan material. Keyakinan akan nilai-nilai tersebut menyebabkan manusia setuju atau tidak setuju terhadap hal-hal yang baik dan buruk, benar maupun salah. (Kamrani Buseri, 1999:15). Menurut Riseri dalam (Musthafa Rahman, 2003:35) nilai menjadi standar perbuatan dan sikap yang menentukan "status" seseorang dan cara hidupnya.

Sedangkan Siti Gazalba dalam (Mawardi Lubis, 2008: 17) mengartikan nilai adalah suatu yang bersifat abstrak dan ideal. Nilai bukan benda konkret, bukan fakta, dan tidak haya sekedar soal penghayatan yang dikehendaki dan tidak dikehendaki, yang disenangi dan tidak disenangi. Nilai itu terletak antara hubungan antara subjek penilai dengan objek.

Berdasarkan beberapa pengertian di atas, bisa digaris bawah nilai merupakan esensi yang melekat pada sesuatu yang sangat berarti bagi kehidupan manusia. Esensi itu sendiri belum berarti belum dibutuhkan manusia, tetapi bukan berarti adanya esensi itu karena adanya manusia yang membutuhkan. Hanya saja kebermaknaan esensi tersebut semakin meningkat sesuai dengan peningkatan daya tangkap dan pemaknaan manusia itu sendiri.

Adapun pengertian pedidikan nilai dalam Zaim Elmubarok (2009:12) sebagaimana yang dikemukan Satrapratedja merupakan penanaman dan pengembangan nilai-nilai pada diri sendiri. Mardimadja juga menyatakan bahwa pendidikan nilai bantuan terhadap peserta didik menyadari dan mengalami nilainilai serta menempatkan secara integral dalam keseluruhan hidupnya.

Pada hakikatnya pendidikan nilai, merupakan inti dari pendidikan itu sendiri. Adapun tujuan pendidikan nilai secara umum yaitu dimaksudkan untuk 
membantuk peserta didik agar memahami, menyadari, dan mengalami nilai-nilai serta mampu menempatkannya secara integral dalam kehidupan.

\section{Strategi Pendidikan Nilai}

Strategi pendidikan nilai menurut Neong Muhadjir dalam buku Chabib Thoha (77-80) menjelaskan bahwa strategi pendidikan nilai terdapat empat model yakni:

a. Strategi Tradisional

Strategi tradisional ini ialah dengan memberikan nasehat atau indoktrinasi. Startegi ini ditempuh dengan jalan memberitahukan secara langsung nilai-nilai mana yang baik dan yang kurang baik. Kelemahan strategi ini adalah Peserta didik sekedar tahu atau hafal jenis-jenis nilai tertentu yang baik dan yang kurang baik, tetapi belum tentu melaksPeserta didikan. Hal ini kurang menguntungkan untuk pendidikan nilai yang seharusnya mengembangkan kesadaran internal pada diri Peserta didik.

b. Strategi Bebas Strategi ini merupakan kebalikan dari strategi tradisional, yakni guru/pendidik tidak memberitahukan kepada Peserta didik nilai-nilai yang baik dan buruk, pembentukan nilai secara bebas ialah memberikan kebebasan sepenuhnya kepada Peserta didik untuk memilih dan menentukan nilai yang akan diambilkan. Kelemahan dari strategi ini adalah Peserta didik belum tentu mampu memilih nilai-nilai mana yang baik dan kurang baik, Peserta didik masih memerlukan bimbingan dari pendidik untuk memilih nilai yang terbaik bagi dirinya.

c. Strategi Reflektif Strategi ini merupakan cara mendidik siswa dalam mengenal dan memilih nilai-nilai ketuhanan dan kemanusiaan dengan jalan mondarmandir antara menggunakan pendekatan teoritik ke pendekatan empirik, serta mondar-mandir antara pendekatan deduktif dengan pendekatan induktif. Bila dalam strategi tradisional guru memiliki peran yang menentukan sebab kebenaran datang dari atas sedang siswa tinggal menerima kebenaran itu tanpa harus mempersoalkan hakekatnya, dan dalam pendekatan siswa bebas memilih dan menentukan nilai-nilai yang benar dan yang salah, maka dalam strategi reflektif ini peran guru dan siswa sama-sama terlibat secara aktif. 
d. Strategi Transinternal Strategi ini merupakan cara untuk mengajarkan nilai dengan jalan melakukan transformasi nilai, dilanjutkan dengan transaksi dan transinternalisasi. Dalam strategi ini guru dan siswa sama-sama terlibat dalam proses komunikasi aktif dan tidak hanya melibatkan komunikasi verbal dan komunikasi fisik, melainkan adanya keterlibatan komunikasi batin (kepribadian) antara guru dan siswa. Guru berperan sebagai penyaji informasi, pemberi contoh dan teladan serta guru sebagai sumber nilai yang melekat dalam pribadinya sedangkan siswa menerima informasi dan merespon terhadap stimulus guru secara fisik biologis, serta memindahkan dan mempolakan pribadinya untuk menerima nilai-nilai kebenaran sesuai dengan kepribadian guru tersebut.

Sedangkan perspektif Islam dalam pendidikan nilai telah terintegrasi atau terkombinasi di alam ini. Namun, beberapa strategi yang tersirat dalam Al-Qur'an dan Hadits menunjukkan perlunya metode khusus yang dapat diringkas sebagai berikut: pertama, strategi praktis (amaliyah) yang dilaksPeserta didikan melalui pembacaan dan eksperimen. Perlu dicatat di sini bahwa ajaran Islam yang disampaikan melalui nasihat dan saran adalah sangat efektif, namun strategi tersebut perlu diimplementasikan dalam kehidupan nyata untuk membentuk kepribadian manusia secara komprehensif. Untuk menginstal siswa dengan kebiasaan baik dan hidup sesuai dengan ajaran Islam, serta mampu menahan keinginan buruk, dan rela berjuang untuk kepentingan umum, budaya perdamaian, dan lain-lain, mereka membutuhkan latihan dan praktek terus menerus sehingga nilai-nilai Islam akan masuk dalam kehidupan sehari-hari mereka.

Menurut Abdurrachman Assegaf Semua program harus mencakup domain kognitif serta afektif dan psikomotorik, dan strategi praktis untuk memberi perhatian pada aspek psikomotor siswa dengan pembelajaran berbasis kompetensi. Pendidikan nilai yang dilaksPeserta didikan hanya melalui aspek kognitif saja tidaklah cukup, meskipun itu sangat penting. Inti dari pendekatan praktis (amaliyah) adalah bahwa mereka menyediakan pelajar dengan kesempatan yang 
cocok untuk berlatih dan menjalani kehidupan mereka sesuai dengan prinsipprinsip dan nilai-nilai yang telah mereka rasakan dan pahami.

\section{Pengertian Karakter}

Karakter dalam kamus besar bahasa Indonesia adalah sifat-sifat kejiwaan, akhlak, atau budi pekerti yang membedakan sesorang dari orang lain, tabiat, watak. (Tim Bahasa Pustaka Agung Harapan, 2003: 300)

Menurut Thomas Likona dalam (Agus Wibowo, 2012: 32-33) karakter merupakan sifat alami seseorang dalam merespons situasi secara bermoral. Sifat alami itu dimanifestasikan dalam tindakan nyata melalui tingkah laku yang baik, jujur, bertanggung jawab menghormati orang lain dan karakter mulia lainnya. Sedangkan menurut Suyanto karakter adalah cara berpikir dan berperilaku yang menjadi ciri khas tiap individu untuk hidup dan berkerja sama, baik dalam lingkup keluarga, masyarakat, bangsa dan bernegara. Individu yang berkarakter baik adalah individu yang membuat keputusan dan sikap mempertanggungjawabkan siap akibat dari keputusan yang dibuat.

Dalam hal ini karakter merupakan istilah yang menunjukan kepada aplikasi nilai-nilai kebaikan dalam bentuk tingkah laku. Walaupun istilah karakter dapat menunjuk kepada karakter baik atau karakter buruk, namun alam aplikasinya orang dikatakan berkarakter jika mengaplikasikan nilainilai kebaikan dalam perilakuknya. (Euis Sunarti, 2005: 1)

\section{Nilai Karakter}

Bedasarkan kajian berbagai agama, norma social, peraturan atau hukum, etik akademik, dan prinsip-prinsip HAM telah teridentifikasi butir-butir nilai yang dikelompokan menjadi lima utama, yaitu nilai-nilai perilaku manusia dalam hubungannya dengan Tuhan Yang Maha Esa, diri sendiri, sesama manusia, lingkungan dan kebangsaan. Berikut deskripsi nilai-nilai utama menurut Jamal Ma"mur Asmani (2011:40):

a. Nilai karakter hubungannya dengan Tuhan, yaitu nilai yang bersifat religious. 
b. Nilai karakter hubungannya dengan diri sendiri, yaitu 1) jujur, 2) bertanggung jawab, 3) bergaya hidup sehat, 4) disiplin, 5) kerja keras, 6) percaya diri, 7) berjiwa wirausaha, 8) berpikir logis, kritis, kretif, dan inovatif, 9) mandiri, 10) ingin tahu, dan 11) cinta ilmu.

c. Nilai karakter hubungannya dengan sesama, yaitu 1) sadar hak dan kewajiban diri dan orang lain, 2) patuh pada aturan-aturan social, 3) menghargai karya dan prestasi orang lain, 4) santun, dan 5) demokratis.

d. Nilai karakter hubungannya dengan lingkungan, yaitu kepedulian terhadap social dan lingkungan serta mencegah kerusakan lingkungan alam dan sekitar.

e. Nilai karakter hubungannya dengan kebangsaan, yaitu 1) nasionalis dan 2) menghargai keberagaman.

Adapun nilai-nilai karakter yang dikembangkan dan ditanamkan oleh pemerintah melalui gerakan nasional di bidang pendidikan adalah sebagaimana yang telah diringkas oleh Kemendiknas (2010) melalui berbagai nilai-nilai luhur yang dimiliki oleh setiap suku-suku bangsa Indonesia sebagai pondasi karakter bangsa. Hal ini dapat dilihat pada tabel sebagai berikut:

\begin{tabular}{|l|l|l|}
\hline No. & \multicolumn{1}{|c|}{ NILAI } & \multicolumn{1}{c|}{ DESKRIPSI } \\
\hline 1. & Religius & $\begin{array}{l}\text { Sikap dan perilaku yang patuh dalam melaksPeserta } \\
\text { didikan ajaran agama yang dianutnya, toleran terhadap } \\
\text { pelaksanaan ibadah agama lain dan hidup rukun dengan } \\
\text { pemeluk agama lain }\end{array}$ \\
\hline 2. & Jujur & $\begin{array}{l}\text { Perilaku yang didasarkan pada upaya menjadikan } \\
\text { dirinya sebagai orang yang selalu dapat dipercaya } \\
\text { dalam perkataan, tindakan dan pekerjaan }\end{array}$ \\
\hline 3. & Toleransi & $\begin{array}{l}\text { Sikap dan tindakan yang menghargai perbedaan agama, } \\
\text { suku, etnis, pendapat, sikap, dan tindakan orang lain } \\
\text { yang berbeda dari dirinya }\end{array}$ \\
\hline 4. & Disiplin & $\begin{array}{l}\text { Tindakan yang menunjukkan perilaku tertib dan patuh } \\
\text { pada berbagai ketentuan dan peraturan }\end{array}$ \\
\hline 5. & Kerja Keras & \begin{tabular}{l} 
Perilaku yang menunjukkan upaya sungguh dalam \\
\hline
\end{tabular}
\end{tabular}




\begin{tabular}{|c|c|c|}
\hline & & $\begin{array}{l}\text { mengatasi berbagai hambatan belajar dan tugas dengan } \\
\text { sebaik-baiknya }\end{array}$ \\
\hline 6. & Kreatif & $\begin{array}{l}\text { Berpikir dan melakukan sesuatu untuk menghasilkan } \\
\text { cara atau hasil baru dari sesuatu yang telah dimiliki }\end{array}$ \\
\hline 7. & Mandiri & $\begin{array}{l}\text { Sikap dan perilaku yang tidak mudah tergantung dari } \\
\text { orang lain dalam menyelesaikan tugastugasnya }\end{array}$ \\
\hline 8. & Demokratis & $\begin{array}{l}\text { Cara berpikir, bersikap dan bertindak yang menilai } \\
\text { sama hak dan kewajiban dirinya dan orang lain }\end{array}$ \\
\hline 9. & Rasa Ingin Tahu & $\begin{array}{l}\text { Sikap dan tindakan yang selalu berupaya untuk } \\
\text { mengetahui lebih mendalam dan meluas dari sesuatu } \\
\text { yang dipelajarinya, dilihat dan didengar. }\end{array}$ \\
\hline 10. & $\begin{array}{l}\text { Semangat } \\
\text { Kebangsaan }\end{array}$ & $\begin{array}{l}\text { Cara berpikir, bertindak dan berwawasan untuk } \\
\text { kepentingan diri dan kelompoknya. }\end{array}$ \\
\hline 11. & Cinta tanah air & $\begin{array}{l}\text { Cara berpikir, bersikap dan berbuat menunjukkan } \\
\text { kesetiaan, kepedulian, dan penghargaan tinggi terhadap } \\
\text { bahasa, lingkungan fisik, sosial, budaya, ekonomi, dan } \\
\text { politik bangsa. }\end{array}$ \\
\hline 12. & $\begin{array}{l}\text { Menghargai } \\
\text { Prestasi }\end{array}$ & $\begin{array}{l}\text { Sikap dan tindakan yang mendorong dirinya untuk } \\
\text { menghasilkan sesuatu yang berguna bagi masyarakat, } \\
\text { mengakui serta menghormati keberhasilan orang lain. }\end{array}$ \\
\hline 13. & $\begin{array}{l}\text { Bersahabat/ } \\
\text { Komunikatif }\end{array}$ & $\begin{array}{l}\text { Tindakan yang memperlihatkan rasa senang berbicara, } \\
\text { bergaul dan bekerja sama dengan orang lain. }\end{array}$ \\
\hline 14. & Cinta damai & $\begin{array}{l}\text { Sikap, perkataan dan tindakan yang menyebabkan } \\
\text { orang lain merasa senang dan aman atas kehadiran } \\
\text { dirinya. }\end{array}$ \\
\hline 15. & Gemar membaca & $\begin{array}{l}\text { Kebiasaan menyediakan waktu untuk membaca } \\
\text { berbagai bacaan yang memberikan kebajikan bagi } \\
\text { dirinya }\end{array}$ \\
\hline 16. & $\begin{array}{l}\text { Peduli } \\
\text { Lingkungan }\end{array}$ & $\begin{array}{l}\text { Sikap dan tindakan yang selalu berupaya mencegah } \\
\text { kerusakan alam lingkungan diantaranya dan }\end{array}$ \\
\hline
\end{tabular}




\begin{tabular}{|l|l|l|}
\hline & & $\begin{array}{l}\text { mengembangkan upaya-upaya untuk memperbaiki } \\
\text { kerusakan alam yang terjadi }\end{array}$ \\
\hline 17. & Peduli sosial & $\begin{array}{l}\text { Sikap dan tindakan yang selalu ingin memberikan } \\
\text { bantuan pada orang lain dan masyarakat yang } \\
\text { membutuhkan }\end{array}$ \\
\hline 18. & Tanggung jawab & $\begin{array}{l}\text { Sikap dan perilaku seseorang untuk melaksPeserta } \\
\text { didikan tugas dan kewajibannya yang seharusnya ia } \\
\text { lakukan terhadap diri sendiri, masyarakat, lingkungan }\end{array}$ \\
\hline
\end{tabular}

\section{METODOLOGI PENELITIAN}

Jenis penelitian yang digunakan adalah penelitian lapangan (field research) yaitu jenis penelitian yang berusaha menghimpun data penelitian secara langsung di lapangan, seperti di lingkungan masyarakat, lembagalembaga dan organisasi kemasyarakatan dan lembaga pendidikan formal maupun non formal. (Sarjono dkk, 2008:21).

Penelitian ini termasuk penelitian kualitatif deskriptif, penyajian data hasil penelitiannya dipaparkan dalam bentuk uraian deskripsi.

\section{HASIL KAJIAN DAN PEMBAHASAN}

\section{Strategi Pendidikan Nilai Dalam Membentuk Karakter Peserta didik Di MI} Matholibul Huda Jenggolo Jenu Tuban

Adapun strategi pendidikan nilai disini peneliti mengintergasikan dari beberapa teroti yang ada, yaitu dari teori Neong Muhajir, teori Abdurahman Assegaff, teori Maksudin dan teori Maragustam sebagai pegangang dan pijakan peneliti dalam menentukan strategi yang digunakan Pendidik di MI Matholibul Huda. Startegi pendidikan nilai yang diterapkan di MI Matholibul Huda ialah sebagai berikut:

\section{Strategi Keteladanan (Modelling)}

Keteladanan merupakan wujud nyata dari tingkah laku seseorang yang dapat diteladani oleh orang lain. Strategi keteladanan (modeling) merupakan strategi yang sangat diperlukan dalam menanamkan nilai atau karakter kepada 
Peserta didik, karena pada dasarnya manusia selalu suka meniru tingkah laku orang lain, Oleh karena itu keteladanan sangat diperlukan. Perencanaan strategi keteladanan di MI Matholibul Huda yang bersifat keteladanan berasal dari diri sendiri pada dasarnya bersifat hidden (tersembunyi) atau tidak direncPeserta didikan, namun pada kegiatan pembelajaran menggunakan strategi keteladanan melalui metode bercerita dengan selalu mempersiapkan dan memberikan kisah ataupun cerita yang dapat diteladani oleh Peserta didik. Dalam Penerapannya Pendidik di MI Matholibul Huda menerapkan pendidikan nilai melalui strategi keteladanan dengan metode teladan dan metode bercerita. Strategi ini dapat dibedakan menjadi dua yaitu strategi keteladanan internal (internal modelling) dan strategi keteladanan ekternal (eksternal modelling).

Keteladanan internal yang dilakukan Pendidik MI Matholibul Huda, misalnya Pendidik selalu mengakhiri dan mengawali setiap pembelajaran dengan mengucapkan salam dan berdoa terlebih dahulu.

Pendidik selalu memberikan contoh untuk dengan menggunakan katakata yang baik dan tidak menyinggung perasaan orang lain, serta memiliki komitmen atas apa yang diucapkan dan telah disepakati bersama. Menjadi suri tauladan yang baik memerlukan proses yang panjang dalam melatih diri sendiri, dengan kebiasaan-kebiasaan dalam menerapkan nilai-nilai yang baik dapat dijadikan teladan dalam bersikap dan berkata oleh Peserta didik.

Sedangkan keteladan eksternal, berupa cerita tentang tokoh-tokoh agama yang dapat dijadikan sebagai teladan dalam menjalani kehidupan. Misalnya, tokoh nabi Muhammad, para sahabat nabi Muhammad, Jenderal Besar Soedirman, dan tokoh- tokoh penting lain baik di Indonesia maupun di luar Indonesia yang patut untuk diteladani. Penyajian cerita yang menarik tentang kisah para tokoh tersebut diharapkan menjadikan Peserta didik mengidolakan dan meniru tindakan positif yang mereka lakukan. Para tokoh tersebut memiliki sikap ketaqwaan, kejujuran, keikhlasan, dan tanggungjawab yang dapat diteladani. Nabi Muhammad merupakan contoh atau teladan sosok manusia yang memiliki ketaqwaan luar biasa yang patut untuk diteladani. Dari 
kegiatan ini dapat memberi manfaat dan dapat dijadikan teladan bagi Peserta didik.

Strategi keteladanan sangat efektif untuk diterapkan karena dari keteladanan tersebut Peserta didik dapat memiliki figur atau sosok yang dapat diteladani. Dengan demikian melalui kepribadian dan tingkah laku yang dilakukan Pendidik serta menggunakan metode cerita dan kisah-kisah yang positif dalam kegiatan kajian siroh dan kajian yang lainnya, Pendidik berharap nilai-nilai yang terkandung di dalamnya dapat menjadi sesuatu yang menarik dan dapat ditiru atau diteladani oleh Peserta didik dalam kehidupan seharihari.

2. Strategi Nasehat (Tradisional)

Nasehat ialah memberikan bimbingan, masukan, pengarahan, mengajak orang untuk mengarah dalam kebenaran dan kebajikan dengan cara menasehati, menyampaikannya dengan cara menyentuh kalbu sehingga dapat menggugah hati dan perasaanya untuk melakukan dan mengamalkannya. Di MI Matholibul Huda strategi nasehat sebagai strategi yang sangat efektif untuk digunakan karena nasehat merupakan saran komunikasi antara Pendidik dan Peserta didik-Peserta didik MI Matholibul Huda.

Strategi nasehat dalam perencanaannya berdasarkan kesempatan yang ada, dimanapun dan kapanpun strategi nasehat dapat digunakan saat diperlukan, Dalam perencanaanya kegiatan tersebut berdasarkan situasi ataupun kondisi tertentu, misalnya saat ujian, Strategi nasihat dapat digunakan untuk membukakan mata Peserta didik-Peserta didik kepada hakekat sesuatu yang mendorongnya menuju situasi luhur, dan menghiasinya dengan akhlak mulia, dan membekalinya dengan prinsip-prinsip Islam.

Bertolak dari uraian diatas, jelaslah bahwa Pendidik dalam memberikan nasihat ini harus menggunakan kata-kata yang halus, yang dapat menyentuh perasaan, sehingga Peserta didik tergugah untuk mengamalkan dalam kehidupan sehari-hari. Dan juga nasihat ini disampaikan lewat cerita, kisah, atau perumpamaan. Berdasarkan hasil wawancara peneliti dengan 
Pendidik MI Matholibul Huda bahwa Pendidik MI Matholibul Huda selalu menerapkan nasehat sebagai strategi yang ampuh dalam menyampaikan nilai.

Penerapan strategi nasehat dalam menanamkan nilai di MI Matholibul Huda dengan mengunakan metode perumpamaan. Dalam penerapannya strategi nasehat ini dapat menanamkan nilai percaya diri, kerja keras, mandiri, kedisiplinan dan kreatif. Nasehat yang diberikan Pendidik kepada Peserta didik di MI Matholibul Huda melalui kegiatan belajar bersama, pada kegiatan ini Pendidik memberikan nasehat yang dapat membangun motivasi Peserta didik dalam belajar dengan tujuan agar cita-citanya tercapai. Kegiatan tersebut menumbuhkan kekuatan, semangat dan rasa percaya diri dalam diri Peserta didik.

Strategi pemberian nasehat dalam menanamkan pendidikan di MI Matholibul Huda diimplementasikan dengan metode perumpamaan. Perumpamaan yang dilakukan oleh Pendidik misalnya dalam kegiatan Muhasabah, Pendidik memberikan Peserta didik nasehat kepada Peserta didik melalui perumpamaan untuk siapa Peserta didik belajar dan untuk siapa prestasi yang didapatkan di sekolah. Dari metode perumpamaan yang diterapkan dapat menanamkan nilai percaya diri dalam diri Peserta didik. Contoh lain yang diterapkan Pendidik dalam menasehati Peserta didik ialah Peserta didik diberikan perumpaan mengenai perbedaan hidup ditempat yang bersih dan hidup ditempat yang kotor, dengan demikian dari perumpaan tersebut Peserta didik akan mengerti bahwa kebersihan merupakan pangkal kesehatan.

Melalui strategi nasehat ini Pendidik dapat membuka mata dan hati Peserta didik untuk selalu berperilaku baik terhadap diri sendiri dan orang lain berdasarkan nilai-nilai yang telah diajarkan. Dengan demikian strategi nasehat dalam menanamkan pendidikan nilai dengan memberikan nasehat kepada Peserta didik dengan cara menasehati sebagaimana seorang keluarga, kakak, adik dan ibu, dengan penuh kasih sayang dan tidak bersifat kemarahan ataupun kekerasan.

3. Strategi Knowing The Good (mengetahui yang baik) 
Strategi knowing the good merupakan strategi dengan memberikan pengetahuan yang baik kepada Peserta didik sesuai dengan kaidah-kaidah dalam pendidikan nilai. Dalam perencanaannya strategi knowing the good ialah dengan memberikan alasan kepada Peserta didik mengenai nilai tersebut. Berdasarkan hasil wawancara peneliti dengan Pendidik MI Matholibul Huda, bahwa implementasi pendidikan nilai yang dilakukan Pendidik MI Matholibul Huda dengan menggunakan strategi memberi pengetahuan nilai yang baik atau bisa dikatakan sebagai strategi knowing the good (mengetahui yang baik) dalam pendidikan nilai/karakter, strategi tersebut diterapkan dalam kegiatan di MI Matholibul Huda seperti kegiatan sharing dan diskusi. Strategi knowing the good merupakan strategi pendidikan nilai/karakter dalam proses pembentukan karakter Peserta didik, dimana Peserta didik tidak hanya sekedar tau mengenai nilai-nilai yang baik, namun Peserta didik harus dapat mengetahui dan memahami alasan dari nilai baik dan nilai yang kurang baik.

Strategi knowing the good dalam proses penerapannya dapat menggunkan pendekatan klarifikasi nilai (value clarification). Karena dalam penerapan dan pelaksanaanya Peserta didik diminta untuk mengklarifikasi terhadap nilai-nilai yang terkandung dalam suatu masalah yang mereka temukan. Penerapan strategi tersebut dapat dilihat melalui kegiatan diskusi dan sharing, misalnya pada saat kajian umum Pendidik menyampaikan masalah atau kasus yang lagi beredar di media massa seperti adanya anak usia dasar yang kedapatan menggunakan narkoba dan obat-obatan terlarang. Dari kasus tersebut Pendidik dan Peserta didik akan menganalisis dan mengklarifikasi nilai positif dan nilai negatif.

Strategi knowing the good yang diimplementasikan dengan menggunakan pendekatan klarifikasi nilai sebagai pendekatan dalam mengganalisis masalah atau kasus ini merupakan sesuatu yang penting dan menarik untuk dilakukan. Permasalahan-permasalahan tentang implementasi dari nilai-nilai seperti nilai kejujuran, ketaqwaan, percaya diri dan tanggung jawab dalam kehidupan sehari-hari sering ditemukan dalam tulisan-tulisan dan artikel-artikel yang sedang aktual untuk dibicarakan. Misalnya, terkait dengan 
nilai kejujuran dan tanggung jawab, sering kali di media massa memuat artikel tentang kasus korupsi dan penyalahgunaan kekuasaan oleh pejabat pemerintahan. Dengan demikian hal inilah yang dapat dijadikan sarana bagi Pendidik di MI Matholibul Huda dalam memberikan pendidikan nilai yang terkandung di dalamnya. Hal terpenting yang perlu diperhatikan dalam menerapkan strategi knowing the good ini bahwa Peserta didik tidak hanya mengetahui suatu nilai namun Peserta didik dapat membedakan dan menklarifikasi alasan mengapa nilai positif dikatakan positif dan sebaliknya.

Dengan demikian setelah mengetahui nilai dan mengklarifikasinya harapannya Peserta didik dapat mengimplementasikannya dalam kehidupan sehari-hari. Sehingga secara perlahan nilai tersebut dapat membentuk kepribadian Peserta didik menjadi Peserta didik yang memiliki kepribadian yang baik.

4. Strategi Pembiasaan (habituasi)

Pembiasaan merupakan strategi yang mudah dilakukan untuk membiasakan Peserta didik berpikir, bersikap dan bertindak dalam menerapkan nilai-nilai positif yang telah di ajarkan. Strategi pembiasaan di MI Matholibul Huda ini direncanakan berdasarkan adanya peraturan dan kegiatan sehari-hari. Kegiatan tersebut berupa memberikan pengetahuan dan menanamkan nilai-nilai positif dan kegiatan tersebut juga berupaya agar Peserta didik mengetahui manfaat dari suatu kegiatan, sehingga Peserta didik dapat terbiasa menerapkannya berdasarkan pemahamannya.

Dalam Penerapannya Pendidik dalam menanamkan pendidikan nilai di MI Matholibul Huda menggunakan strategi pembiasaan melalui pendekatan pembelajaran berbuat (Action learning approach) sebagai bentuk pendekatan yang memberikan kesempatan kepada Peserta didik untuk melakukan perbuatan-perbuatan baik secara perserorangan maupun bersama-sama melalui kegiatan yang biasa dilakukan Peserta didik. Strategi pembiasaan (habituasi) yang baik ini meliputi, pembiasaan yang melibatkan diri sendiri dan pembiasaan yang melibatkan orang lain. 
Berberapa pendidikan nilai dapat ditanamkan melalui strategi pembiasaan (habituasi) yang baik seperti kedisiplinan, keikhlasan, kemandirian, percaya diri, tanggung jawab. Pembiasaan yang baik yang meliputi pembiasaan diri sendiri yaitu dilakukan melalui kegiatan yang ada, misal Peserta didik dibiasakan menyetor hafalan "one day one ayat" (satu hari satu ayat), kebiasaan tersebut dapat menjadikan Peserta didik yang disiplin dan bertanggung jawab pada diri sendiri. Demikian juga dengan kebiasaan dalam kegiatan belajar keterampilan membuat bros, membuat bunga, yang dapat mengasah kreativitas serta menjadikan Peserta didik kreatif dan mandiri.

Sedangkan pembiasaan yang meliputi orang lain misalnya dalam kegiatan jadwal piket kebersihan harian, kegiatan ini yang dapat membangun nilai tanggung jawab, tidak hanya tanggung jawab pada diri sendiri juga tanggung jawab bersama dan membutuhkan kerja sama agar tugas kebersihan dapat terlaksana. Strategi pembiasaan (habitusi) yang baik melalui Pendekatan pembelajaran berbuat (action learning approach) memberikan Peserta didik kebebasan dan kesempatan dalam berbuat berdasarkan kebiasaan yang dilakukan.

Dalam pengertian secara luas rutinitas itu sendiri sebagai kebiasaan dan kebiasaan itu sendiri sebagai pembentuk karakter. Tidak dapat dipungkiri bahwa kebiasaan merupakan strategi yang sangat efektif dalam menanamkan nilai dalam diri Peserta didik sehingga membentuk suatu karakter yang melekat seiring dengan kebiasaan yang Peserta didik lakukan. Dengan demikian strategi pembiasaan ini merupakan strategi yang sangat efektif jika digunakan dalam menanamkan nilai kepada Peserta didik melalui kebiasaan yang dilakukan, dari pembiasaan yang dilakukan maka akan menjadi kebiasaan dan pada akhirnya kebiasaan tersebut melekat terbentuk menjadi karakter dalam diri Peserta didik.

5. Strategi Feeling and loving the good (merasakan hal yang baik)

Berdasarkan hasil wawancara peneliti dengan Pendidik MI Matholibul Huda bahwa dalam mengajarkan dan menanamkan pendidikan nilai Pendidik menggunakan strategi kesadaran dari suatu nilai, dan dapat peneliti simpulkan 
bahwa strategi tersebut dapat dikatakan strategi feeling and loving the good (merasakan hal yang baik). Strategi feeling and loving the good merupakan strategi pendidikan karakter/nilai ialah sebagai suatu konsep dengan mencoba membangkitkan rasa cinta (loving knowlage) dan kerinduan (desering knowlage) Peserta didik untuk melakukan perbuatan baik, dalam artian Peserta didik dilatih untuk merasakan efek dari suatu perbuatan baik.

Dalam perencanaan strategi feeling and loving the good yang dilakukan Pendidik sebagai bentuk pemberian kesempatan kepada Peserta didik untuk melakukan suatu kegiatan berdasarkan keinginan dan kesadaran Peserta didik masing-masing, sehingga dalam melaksanakannya peserta didik memahami dan menyadari atas apa yang peserta didik lakukan. Strategi feeling and loving the good ini diimplementasikan dengan menggunakan pendekatan pembelajaran berbuat (action learning approach) dalam pendidikan nilai, karena pendekatan ini memberikan kesempatan kepada Peserta didik untuk melakukan perbuatan-perbuatan baik sesuai dengan nilainilai yang dimiliki Peserta didik.

Implementasi strategi feeling and loving the good ini diterapkan oleh Pendidik di luar pembelajaran misalnya kegiatan ekstrakurikuler. Feeling and loving the good dapat juga diterapkan melalui semacam tulisan-tulisan yang dibuat misalnya dengan adanya tulisan atau banner yang ditempel di dinding seperti "jagalah kebersihan", "senyum, salam, sapa, sopan dan santun" kalimat-kalimat seperti ini bisa tersalurkan dalam hati Peserta didik untuk merasakan dan sehingga dapat diterapkan oleh Peserta didik sebagai interaksi dan bertemu dengan teman, pengurus dan Pendidik dengan mengucapakn salam, senyum dan berperilaku sopan terhadap orang lain, serta selalu menjaga kebersihan dengan tidak membuang sampah pada tempatnya.

Dengan demikian implementasi strategi feeling and loving of the good yang ada diMI Matholibul Huda bertujuan untuk memberikan kesempatan kepada Peserta didik dalam mengimplementasikan dari semua nilai-nilai positif yang telah diajarkan sehingga nilai tersebut memberikan pengalaman dan manfaat dalam diri Peserta didik 


\section{KESIMPULAN DAN SARAN}

Dari hasil penelitian dan analisis bahwa strategi pendidikan nilai yang diterapkan di MI Matholibul Huda Jenggolo Jenu Tuban berhasil menanamkan pendidikan nilai dalam diri peserta didik. Adapun strategi yang digunakan ialah sebagai berikut: strategi keteladanan, strategi nasehat (tradisional), strategi knowing the good (mengetahui yang baik), strategi pembiasaan (habituasi) dan strategi feeling and loving the good (merasakan hal yang baik).

Berdasarkan nilai-nilai yang telah diajarkan dan diterapkan melalui sikap dan tingkah laku peserta didik, dapat berdampak pada karakter yang diperlihatkan ialah meliputi karakter berkata jujur, disiplin, tanggungjawab, kerja keras, mandiri, kreatif, percaya diri, ikhlas, religious, kasih sayang, bersahabat dan komunikatif, bergaya hidup sehat, berani, peduli sosial, sopan dan santun.

\section{DAFTAR PUSTAKA}

Asmani ,Jamal Maemur. 2011. Buku Internalisasi Pendidikan Karakter di Sekolah, Yogyakarta: Diva Press.

Buseri, Kamrani. 1999. Nilai-Nilai Ilahiyah, Jakarta: Remaja Pelajar.

Elmubarok, Zaim. 2009. Membumikan Pendidikan Nilai: Mengumpulkan Yang Terserak,Menyambung Yang Terputus, Dan Menyatuhkan Yang Tercerai, Bandung: Alfabeta,

Harapan, Tim Bahasa Pustaka Agung. 2003. Kamus Cerdas Bahasa Indonesia Terbaru, Surabaya: CV Pustaka Agung Harapan.

Lubis, Mawardi. 2008. Evaluasi Pendidikan Nilai, Perkembangan Moral Keagamaan

Mahasiswa Ptain, Yogyakarta: pustaka pelajar.

Rahman, Musthafa. 2003. “Abdullah Nasih Ulwan: Pendidikan Nilai”, Pemikiran Islam Kontemporer, Yogyakarta: Jendela

Sarjono, dkk. 2008. Panduan Penulisan Skripsi Jurusan Pendidikan Agama Islam, Yogyakarta: Jurusan Pendidikan Agama Islam, Fakultas Tarbiyah UIN Sunan Kalijaga. 
Sunarti, Euis. 2005. Menggali Kekuatan Cerita, Jakarta: PT Elex Media Komputindo,

Thoha, Chabib.1996. Kapita Selekta Pendidikan Islam, Yogyakarta: Pustaka Pelajar,

Wibowo, Agus. 2012. Pendidikan Karakter Strategi Membangun Karakter Bangsa Berperadaban, Pustaka Pelajar: Jakarta. 